Michal Rendoš, Dana Miklisová, L'ubomír Kováč, and Andrej Mock. Dynamics of Collembola (Hexapoda) in a forested limestone scree slope, Western Carpathians, Slovakia. Journal of Cave and Karst Studies, v. 82, no. 1, p. 18-29. DOI:10.4311/2018LSC0140

\title{
DYNAMICS OF COLLEMBOLA (HEXAPODA) IN A FORESTED LIMESTONE SCREE SLOPE, WESTERN CARPATHIANS, SLOVAKIA
}

\author{
Michal Rendoš ${ }^{1, C}$, Dana Miklisová2 ${ }^{2}$ L'ubomír Kováč $^{3}$, and Andrej Mock ${ }^{3}$
}

\begin{abstract}
A labyrinth of air-filled voids in forested scree slopes represents one of the most common types of terrestrial shallow subterranean habitats in the temperate zone, characterized by relatively strong seasonal fluctuations of temperature and the occurrence of subterranean species of invertebrates. We carried out a year-long study to define the monthly activity dynamics of Collembola communities inhabiting a depth profile ( $95 \mathrm{~cm}$ from the ground surface) of a forested limestone scree in the Western Carpathians, Slovakia. We assessed the response of species sorted into four separate ecological forms, reflecting their affinity to the subterranean environment and to temperature parameters fluctuating over the year. Of the 62 collembolan species identified, 28 were assigned to trogloxenes, 19 to subtroglophiles, 12 to eutroglophiles, and 3 to troglobionts. Fluctuations of activity/numbers during the year were observed in all four ecological forms of Collembola and at all depths. Troglobionts and eutroglophiles, associated predominantly with deeper layers of the scree slope profile, preferred the lower temperature ranges and were typical for the autumn months. Trogloxenes and subtroglophiles were active most of the year near the surface, but specifically during the spring months characterized by higher temperature ranges. The study contributes to the general knowledge of dynamics of invertebrate activity in a forested temperate zone scree slope.
\end{abstract}

\section{Introduction}

The interior of forested scree slopes at the foot of steep valley sides comprises a relatively common type of terrestrial shallow subterranean habitat in the temperate climate zone (Culver and Pipan, 2008, 2014). The Milieu Souterrain Superficiel (MSS), as this habitat is generally referred to (Juberthie et al., 1980, 1981), lies between the base of the soil horizon and bedrock and consists of an extensive network of lightless air-filled voids that formed within the multiple layers of fragmented rocks. In karst areas, the network of voids is ordinarily interconnected with deep subterranean habitats (i.e., caves, along with adjacent narrow fissures formed in the limestone bedrock) (Juberthie, 1983, 2000; Juberthie and Decu, 2004; Giachino and Vailati, 2010; Mammola et al., 2016). Compared to the deepest parts of the caves, where the temperature fluctuates only minimally during the year, an MSS habitat with a developed soil layer is still largely influenced by the seasonality of the above-ground weather (Pipan et al., 2010; Mammola et al., 2016). Although the temperature regime inside forested scree slopes is characterized by a reduction of temperature extremes, as well as by moderating daily temperature fluctuations, it usually exhibits relatively strong seasonal temperature variations (e.g. Nitzu et al., 2006-2007; Zacharda et al., 2007; Rendoš et al., 2012; Gilgado et al., 2014; Mammola et al., 2017).

The proximity of soil and deep cave habitats causes the scree slope interior to be populated by diverse invertebrate fauna varying in affinity to the subterranean environment. Besides the invertebrate species typically found to inhabit soil, subterranean species known from caves, many of them with apparent morphological adaptations to life in a constantly dark environment, occur in this habitat (Juberthie, 2000; Nitzu et al., 2014; Jiménez-Valverde et al., 2015; Mammola et al. 2016; Rendoš et al., 2016). Despite the intensive research on shallow subterranean habitats conducted in several European countries over the last decades (e.g. Juberthie et al., 1980; Rǔžička and Klimeš, 2005; Giachino and Vailiati, 2010; Laška et al., 2011; Pipan et al., 2010; Nitzu et al., 2014; Jiménez-Valverde et al., 2015; Mammola et al., 2017), very little is still known about the impact of seasonal temperature variations on the activity of particular invertebrate species living therein. Previous authors (e.g. Racovitza and Şerban, 1982; Rendoš et al., 2012, Nitzu et al., 2014) have pointed out that the activity of various invertebrate groups inhabiting shallow subterranean habitats fluctuates considerably throughout the year. Crouau-Roy et al. (1992) observed the abundance of the troglobitic beetle Speonomus hydrophilus (Jeannel, 1907) to be associated with seasonal temperature changes that occurred in the MSS; it markedly declined in both summer and winter.

We carried out a year-long study focused on Collembola, one of the most diversified groups of invertebrates in subterranean habitats (Deharveng, 2004), inhabiting a limestone forested scree slope in the Western Carpathians, Slovakia. Our aim was: (1) to describe the activity dynamics of collembolan communities along the scree profile during the year, and (2) to assess the response of particular collembolan species to temperature parameters fluctuating over the

${ }^{1}$ Department of Ecology, Faculty of Humanities and Natural Sciences, University of Prešov, 17. novembra 1, SK-08116, Prešov, Slovakia.

${ }^{2}$ Institute of Parasitology, Slovak Academy of Sciences, Hlinkova 3, SK-04001, Košice, Slovakia.

${ }^{3}$ Institute of Biology and Ecology, Faculty of Science, P.J. Šafárik University, Šrobárova 2, SK-04154, Košice, Slovakia.

cCorresponding Author: michal.rendos@gmail.com 
year. We hypothesized that subterranean species of Collembola would prefer, unlike the common soil-dwelling species, narrow ranges of temperature and would be active in the scree slope predominantly in cooler months. We expected all collembolans to be frost-sensitive.

\section{Material and Methods}

\section{Study Site}

The Sivec Nature Reserve, located $8 \mathrm{~km}$ southwest of the village of Malá Lodina in Eastern Slovakia, is a small karst island within the Čierna Hora Mountains (Western Carpathians, Central Europe) built predominantly on old crystalline rocks (Hochmuth, 2008). The reserve territory, with an area of $1.7 \mathrm{~km}^{2}$, includes the approximately $1.5 \mathrm{~km}$ long upper part of the Malý Ružínok Valley along with an extensive Mesozoic limestone cliff on the valley's left side, flanked by steep scree slopes. Several shallow caves harbouring endemic invertebrates, including Collembola, have formed inside the cliff (Mock and Tajovský, 2008; Kováč and Papáč, 2010).

The study site has a typical northern temperate climate. According to climatic data provided by the nearby meteorological station of the Slovak Hydrometeorological Institute in the village of Košická Belá, the mean annual temperature (November $2008-O c t o b e r 2009$ ) was $+10.6{ }^{\circ} \mathrm{C}$, and the average annual precipitation was $61.2 \mathrm{~mm}$. The coldest month was January with an average monthly temperature of $-2.9^{\circ} \mathrm{C}$, and the warmest was July $\left(+21.6^{\circ} \mathrm{C}\right)$. The highest precipitation amounts were recorded in December $(96.5 \mathrm{~mm})$ and the lowest in November $(21.7 \mathrm{~mm})$. A layer of snow covered the nature reserve continuously from late January to early March. More details about the climatic characteristics are given in Figure 1.

The sampling stand (coordinates: $48^{\circ} 50.5^{\prime} \mathrm{N}, 21^{\circ} 06.6^{\prime} \mathrm{E}$ ) is situated a few metres below the top of an $15-20^{\circ}$ inclined forested scree slope facing north-east at an altitude of $530 \mathrm{~m}$ and overgrown with Tilieto-Aceratum forest and a scarce herbal layer formed by Asplenium alternifolium, Dentaria sp., Lamium sp., Mercurialis perennis, Urctica dioica, young seedlings of Sambucus sp., and ferns. The investigated scree slope profile consists of three distinct layers: leaf litter and humus $(0-15 \mathrm{~cm})$, an organo-mineral layer $(15-45 \mathrm{~cm})$ clearly separated from scree that occupies a horizon from $45 \mathrm{~cm}$ downwards and is formed by rock fragments with a diameter of 10-15 cm. The dominant soil type on the stand was rendzina (FAO classification of soil types) (IUSS Working Group WRB, 2015).

\section{Sampling and Species Determination}

To sample Collembola, subterranean pitfall traps were buried once beneath the scree slope surface after Schlick-Steiner and Steiner (2000). Each trap consisted of a plastic cylinder (length $110 \mathrm{~cm}$, diameter $10.5 \mathrm{~cm}$ ) circumferentially perforated by openings (diameter $0.8 \mathrm{~cm}$ ) at ten regular horizontal levels $(5,15,25$, up to $95 \mathrm{~cm})$. A demountable set of 10 plastic cups (volume $500 \mathrm{ml}$ ) filled with $4 \%$ formaldehyde preservative solution was inserted into the plastic cylinder interior. The cups were placed right under the openings on the cylinder surface, enabling individuals to be trapped at the particular level (for more details on subterranean trap design, see Rendoš et al., 2016). A triplet of subterranean pitfall traps were placed $50 \mathrm{~cm}$ from one another over a previously excavated pit more than a metre deep. Thereafter, the pit was backfilled with the dugout soil and rocks in the original order of the layers and the tops of cylinders were tightly closed with a plastic lid. The plastic cups were pulled out of the plastic cylinder and emptied once a month, from November 2008 to October 2009. The individuals trapped were poured into plastic bottles, transferred to the laboratory and sorted to the level of higher taxa. Collembola were mounted on permanent microscopic slides after Rusek (1975) and determined to the species level using a Leica DM1000 phase-contrast microscope and identification keys, such as those by Pomorski (1998), Bretfeld (1999), Potapov (2001), Thibaud et al. (2004), and others. Based on the experience of biospeleological inventories carried out in the Slovak caves in the past decades (e.g., Kováč, 2000; Kováč et al., 2016), the Collembola species were divided into four ecological forms reflecting their degree of affinity for subterranean environment, as proposed by Sket (2008): (1) Trogloxenes - species inhabiting the ground surface and uppermost layers of the soil horizon (leaf litter and humus). Their occurrence in subterranean habitats is accidental, as they are unable to reproduce and complete their life cycle in them; (2) Subtroglophiles - species commonly found in subterranean habitats but still intimately interacting with the surface and uppermost layers of the soil horizon during certain periods to complete some of their biological functions, such as dispersal, feeding, or reproduction; (3) Eutroglophiles - essentially edaphic species that are able to maintain permanent and self-sustaining subterranean populations; and (4) Troglobionts - species exclusively inhabiting subterranean habitats.

\section{Temperature Measurements}

The temperature was measured continuously throughout the study period at four-hour intervals using two series of iButton DS1921G thermo-data loggers affixed to the top of the plastic lid (=surface) closing the subterranean trap and to the walls of plastic cups at the depths of 15, 35, 55, 75 and $95 \mathrm{~cm}$. For each sampling period and each measured depth, the temperature data were converted into the following variables: monthly temperature mean (Tmean), monthly temperature maximum (Tmax) and minimum $(T \min )$, and derived monthly temperature range $(\operatorname{Trange}=\operatorname{Tmax}-\operatorname{Tmin})$. 
Both thermo-data loggers placed at $75 \mathrm{~cm}$ stopped functioning for a long period, which caused incomplete temperature data from this depth.

\section{Data Analysis}

The values of monthly collembolan activity were calculated as the average number of individuals sampled by the triad of subterranean traps standardized for 30 days ( 1 month). The dynamics of collembolan activity during the study period were depicted graphically for each depth and ecological form separately. We performed redundancy analysis (RDA) to evaluate associations of collembolan communities from four depths $(15,35,55$ and $95 \mathrm{~cm})$ with 12 months and the measured temperature parameters. In this analysis, depth, month, temperature mean and temperature average were employed as explanatory variables. Response variables were represented by the activity of selected collembolan species based on numbers. To obtain a clear ordination plot, only species with total activity $\geq 5$ (19 species altogether) were included in the analysis, covering $98.5 \%$ of total collembolan numbers. A log-transformation was applied to the data. The analyses were performed using Canoco for Windows 5 software package (Ter Braak and Šmilauer, 2012).

\section{Results}

\section{Temperature Characteristics}

The temperature regime recorded within the scree slope profile was characterized by gradual reduction of daily temperature fluctuations with increasing depth (i.e., the temperature remained constant for several consecutive days in deeper layers of the scree slope profile; for more details, see Figure 1 in Rendoš et al., 2012). Deeper under the surface, the long-term temperature fluctuations still coincided with the seasonal climate variations occurring on the surface (Fig. 1). In winter, the temperature dropped below the freezing point only on the surface for a few days at the turn of December and January, with the lowest recorded temperature of $-4.0^{\circ} \mathrm{C}$. The monthly temperature means increased from the surface downwards, while the monthly temperature ranges were gradually diminished by increasing depth. During the year, the monthly temperature means on the surface ranged between $0.2^{\circ} \mathrm{C}$ (January) to $16.6{ }^{\circ} \mathrm{C}$ (July). In contrast, these means at the depth of $95 \mathrm{~cm}$ ranged between $3.5^{\circ} \mathrm{C}$ (March) to $15.2{ }^{\circ} \mathrm{C}$ (August). Monthly temperature ranges varied from $5.0^{\circ} \mathrm{C}$ (February) to $12.5^{\circ} \mathrm{C}$ (September) on the surface and from $0.5^{\circ} \mathrm{C}$ (February, March) to 4.5 ${ }^{\circ} \mathrm{C}$ (June) at $95 \mathrm{~cm}$ (Table 1).

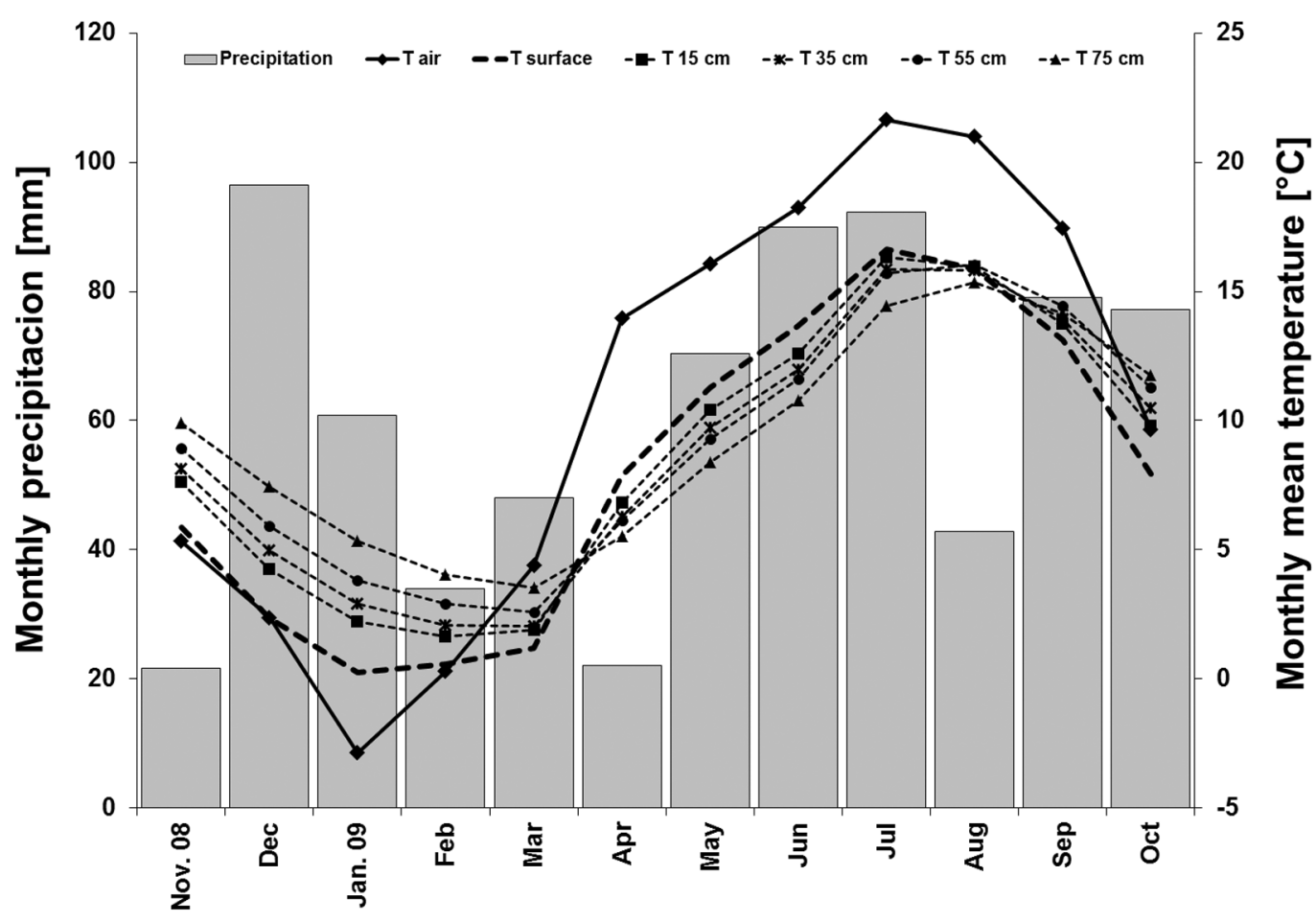

Month

Figure 1. Monthly data of mean air temperature ( $T$ air) and precipitation recorded by the nearest meteorological station in the village of Košická Belá along with monthly data of mean air temperature during the study period (Nov. 2008-Oct. 2009) measured by thermo-data loggers on the soil surface (T surface) and at the depths of $15 \mathrm{~cm}$ (T 15), $35 \mathrm{~cm}$ (T 35), $55 \mathrm{~cm}$ (T 55), and $95 \mathrm{~cm}$ (T 95).

\section{Diversity and Seasonal Dynamics of Collembo- lan Communities}

In the course of the study, more than 17,000 Collembola individuals representing 62 species were trapped across the depth profile by a triplet of subterranean pitfall traps. Variations in collembolan activity and species number among the triplet of traps buried in the scree slope profile can be seen in Appendix 1. Of the total species number identified, 28 species were assigned to trogloxenes ( $n=486)$, 19 to subtroglophiles ( $n$ = 14,619), 12 to eutroglophiles $(n=1821)$ and 3 to troglobionts ( $n=353$ ) (Table 2). At the depths of 5 to $25 \mathrm{~cm}$, we found the species number to be the highest between April and June. Deeper in the scree 
Table 1. Monthly temperature characteristics recorded along the scree slope profile.

\begin{tabular}{|c|c|c|c|c|c|}
\hline \multirow[b]{2}{*}{ Month } & \multirow{2}{*}{$\begin{array}{c}\text { Depth, } \\
\text { cm }\end{array}$} & \multicolumn{4}{|c|}{ Monthly temperature, ${ }^{\circ} \mathrm{C}$} \\
\hline & & Mean & Min & Max & Range \\
\hline \multicolumn{6}{|c|}{ November 2008} \\
\hline & Surface & 7.0 & 1.8 & 12.3 & 10.5 \\
\hline & 15 & 8.5 & 5.0 & 11.5 & 6.5 \\
\hline & 35 & 9.0 & 6.3 & 11.5 & 5.3 \\
\hline & 55 & 9.7 & 7.5 & 11.5 & 4.0 \\
\hline & 75 & $\ldots$ & $\ldots$ & $\ldots$ & $\ldots$ \\
\hline & 95 & 10.5 & 9.0 & 11.8 & 2.8 \\
\hline \multicolumn{6}{|c|}{ December 2008} \\
\hline & Surface & 2.4 & -1.3 & 6.0 & 7.3 \\
\hline & 15 & 4.3 & 2.5 & 5.5 & 3.0 \\
\hline & 35 & 5.1 & 3.8 & 6.8 & 3.0 \\
\hline & 55 & 6.1 & 5.0 & 7.8 & 2.8 \\
\hline & 75 & $\cdots$ & $\cdots$ & $\ldots$ & $\cdots$ \\
\hline & 95 & 7.6 & 6.5 & 9.0 & 2.5 \\
\hline \multicolumn{6}{|l|}{ January 2009} \\
\hline & Surface & 0.2 & -2.3 & 3.5 & 5.8 \\
\hline & 15 & 2.2 & 1.5 & 2.5 & 1.0 \\
\hline & 35 & 2.9 & 2.3 & 3.8 & 1.5 \\
\hline & 55 & 3.8 & 3.0 & 5.0 & 2.0 \\
\hline & 75 & $\ldots$ & $\ldots$ & $\cdots$ & $\ldots$ \\
\hline & 95 & 5.4 & 4.5 & 6.5 & 2.0 \\
\hline \multicolumn{6}{|c|}{ February 2009} \\
\hline & Surface & 0.6 & 0.0 & 5.0 & 5.0 \\
\hline & 15 & 1.6 & 1.5 & 2.5 & 1.0 \\
\hline & 35 & 2.1 & 1.8 & 2.5 & 0.8 \\
\hline & 55 & 2.9 & 2.5 & 3.0 & 0.5 \\
\hline & 75 & $\ldots$ & $\ldots$ & $\ldots$ & $\ldots$ \\
\hline & 95 & 4.0 & 3.8 & 4.3 & 0.5 \\
\hline \multicolumn{6}{|l|}{ March 2009} \\
\hline & Surface & 1.5 & -1.0 & 8.3 & 9.3 \\
\hline & 15 & 2.1 & 1.0 & 4.5 & 3.5 \\
\hline & 35 & 2.2 & 1.5 & 3.8 & 2.3 \\
\hline & 55 & 2.7 & 2.5 & 3.5 & 1.0 \\
\hline & 75 & $\ldots$ & $\cdots$ & $\cdots$ & $\cdots$ \\
\hline & 95 & 3.5 & 3.5 & 4.0 & 0.5 \\
\hline \multicolumn{6}{|l|}{ April 2009} \\
\hline & Surface & 8.4 & 5.5 & 12.8 & 7.3 \\
\hline & 15 & 7.4 & 5.0 & 8.5 & 3.5 \\
\hline & 35 & 6.9 & 4.3 & 7.8 & 3.5 \\
\hline & 55 & 6.7 & 4.0 & 7.8 & 3.8 \\
\hline & 75 & $\cdots$ & $\cdots$ & $\cdots$ & $\cdots$ \\
\hline & 95 & 6.0 & 4.0 & 7.3 & 3.3 \\
\hline \multicolumn{6}{|l|}{ May 2009} \\
\hline & Surface & 11.6 & 8.0 & 16.8 & 8.8 \\
\hline & 15 & 10.8 & 8.5 & 13.0 & 4.5 \\
\hline & 35 & 10.2 & 7.8 & 12.0 & 4.3 \\
\hline & 55 & 9.8 & 7.8 & 11.3 & 3.5 \\
\hline & 75 & $\ldots$ & $\ldots$ & $\ldots$ & $\ldots$ \\
\hline & 95 & 9.0 & 7.3 & 10.3 & 3.0 \\
\hline \multicolumn{6}{|l|}{ June 2009} \\
\hline & Surface & 15.3 & 10.0 & 19.3 & 9.3 \\
\hline & 15 & 14.2 & 11.0 & 16.5 & 5.5 \\
\hline & 35 & 13.4 & 10.3 & 15.8 & 5.5 \\
\hline & 55 & 12.8 & 10.0 & 15.5 & 5.5 \\
\hline & 75 & $\cdots$ & $\ldots$ & $\ldots$ & $\cdots$ \\
\hline & 95 & 11.7 & 9.8 & 14.3 & 4.5 \\
\hline \multicolumn{6}{|l|}{ July 2009} \\
\hline & Surface & 16.6 & 13.0 & 20.5 & 7.5 \\
\hline & 15 & 16.4 & 14.5 & 18.5 & 4.0 \\
\hline & 35 & 16.0 & 14.5 & 17.5 & 3.0 \\
\hline & 55 & 16.0 & 15.0 & 17.5 & 2.5 \\
\hline & 75 & 15.3 & 14.3 & 16.0 & 1.8 \\
\hline & 95 & 14.9 & 14.0 & 15.3 & 1.3 \\
\hline
\end{tabular}

Table 1. (Continued).

\begin{tabular}{|c|c|c|c|c|c|}
\hline \multirow[b]{2}{*}{ Month } & \multirow{2}{*}{$\begin{array}{c}\text { Depth, } \\
\text { cm }\end{array}$} & \multicolumn{4}{|c|}{ Monthly temperature, ${ }^{\circ} \mathrm{C}$} \\
\hline & & Mean & Min & Max & Range \\
\hline \multicolumn{6}{|l|}{ August 2009} \\
\hline & Surface & 15.2 & 10.0 & 20.0 & 10.0 \\
\hline & 15 & 15.5 & 11.0 & 17.0 & 6.0 \\
\hline & 35 & 15.5 & 11.5 & 17.0 & 5.5 \\
\hline & 55 & 15.8 & 13.5 & 17.0 & 3.5 \\
\hline & 75 & 15.3 & 13.8 & 16.3 & 2.5 \\
\hline & 95 & 15.2 & 14.3 & 15.8 & 1.5 \\
\hline \multicolumn{6}{|c|}{ September 2009} \\
\hline & Surface & 11.2 & 3.5 & 16.0 & 12.5 \\
\hline & 15 & 12.4 & 8.0 & 14.5 & 6.5 \\
\hline & 35 & 12.8 & 9.0 & 14.0 & 5.0 \\
\hline & 55 & 13.4 & 10.8 & 14.8 & 4.0 \\
\hline & 75 & 13.3 & 11.3 & 14.8 & 3.5 \\
\hline & 95 & 13.4 & 11.8 & 14.8 & 3.0 \\
\hline \multicolumn{6}{|l|}{ October 2009} \\
\hline & Surface & 5.6 & 1.5 & 10.5 & 9.0 \\
\hline & 15 & 7.4 & 5.5 & 9.5 & 4.0 \\
\hline & 35 & 8.3 & 7.0 & 10.0 & 3.0 \\
\hline & 55 & 9.1 & 7.8 & 10.8 & 3.0 \\
\hline & 75 & 9.5 & 8.3 & 11.8 & 3.5 \\
\hline & 95 & 10.0 & 8.5 & 11.8 & 3.3 \\
\hline
\end{tabular}

slope profile, the species number increased rather tardily from the end of winter and attained the maximum values at the turn of summer and autumn (August, September).

Looking at overall seasonal dynamics of locomotory activity in particular ecological forms of Collembola, we found troglobionts to have the lowest activity among the other forms (Fig. 2). Throughout the study period, the presence of troglobionts was concentrated primarily in the deeper layers of the scree slope profile $(65-95 \mathrm{~cm})$. Activity of troglobitic collembolans increased slightly from the beginning of spring (March) to early summer (June). After a mild summer decline, an autumn increase of troglobiont activity was recorded. In contrast, trogloxenes occurred almost exclusively in the uppermost level $(5 \mathrm{~cm})$ of the depth profile during the year, with maximum activity registered in spring (April-June). Unlike the previous two ecological forms, eutroglophiles and subtroglophiles were active across the entire depth profile throughout the year. At most depths, the activity of eutroglophiles had a similar pattern, characterized by the gradual increase from the end of winter (March) to spring (April, May). After an apparent decrease in summer, the activity of eutroglophiles increased again, reaching a second peak at the end of summer (August), which continued at the deepest levels (85 and $95 \mathrm{~cm}$ ) until the following autumn months (September, October). At the depths of 55 to $85 \mathrm{~cm}$, the second peak of eutroglophile activity was more pronounced than the first one. During the year, the highest activity of subtroglophiles was recorded at the uppermost levels ( 5 and $15 \mathrm{~cm}$ ), with the maximum values attained in April. At most deeper layers of the scree slope profile, two rather prolonged activity peaks were observed during the year in subtroglophiles: the first at the turn of spring and 


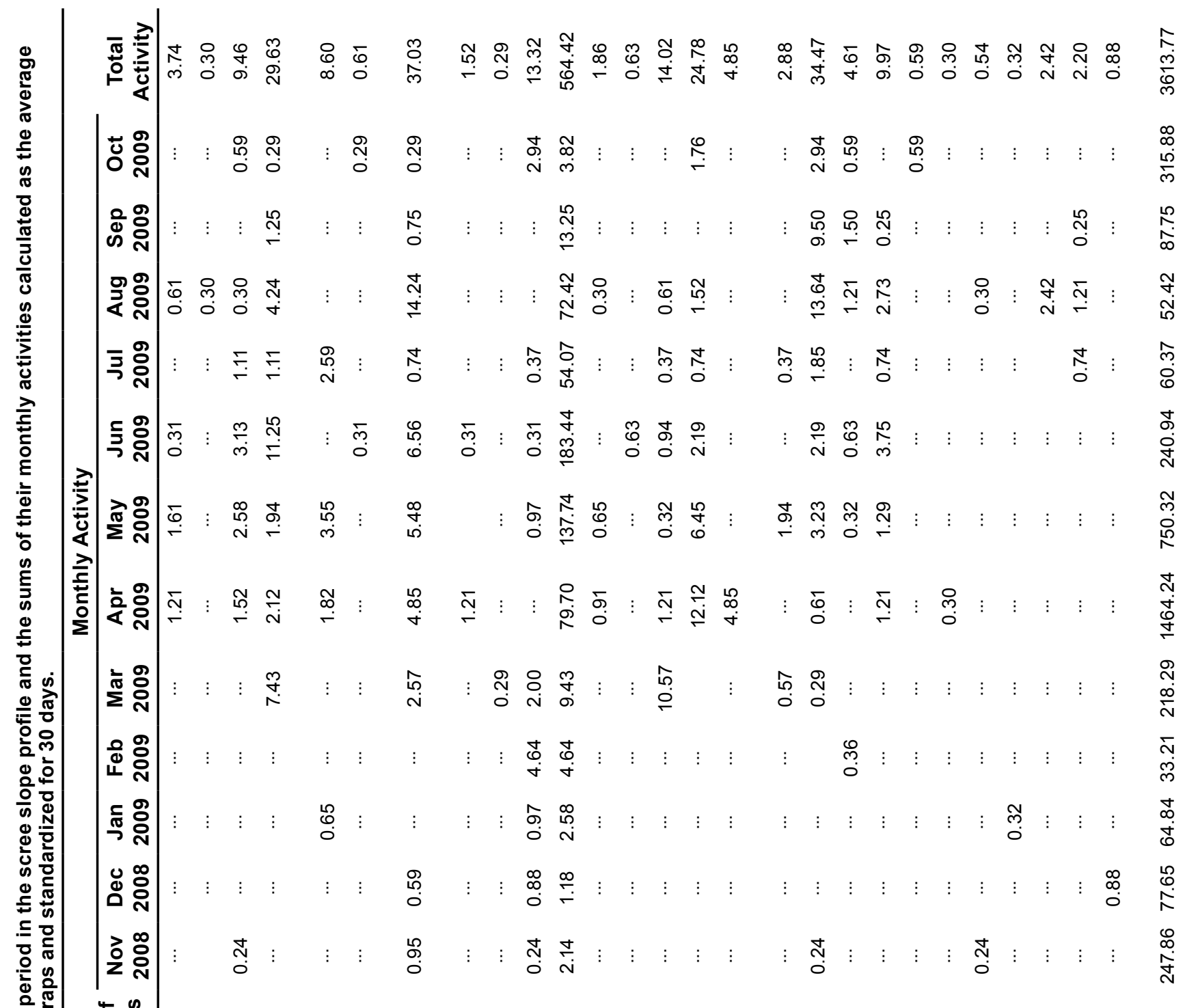

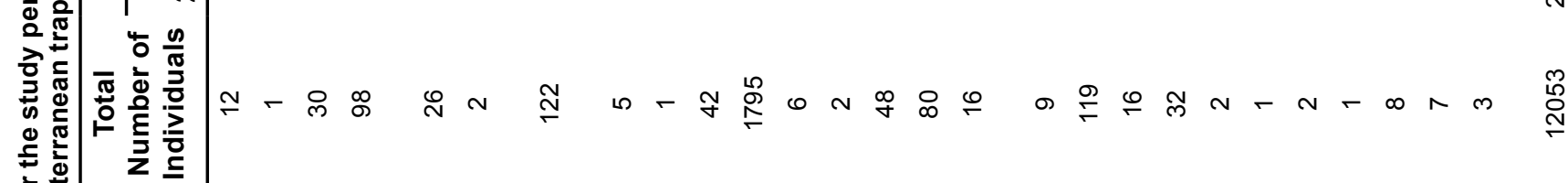

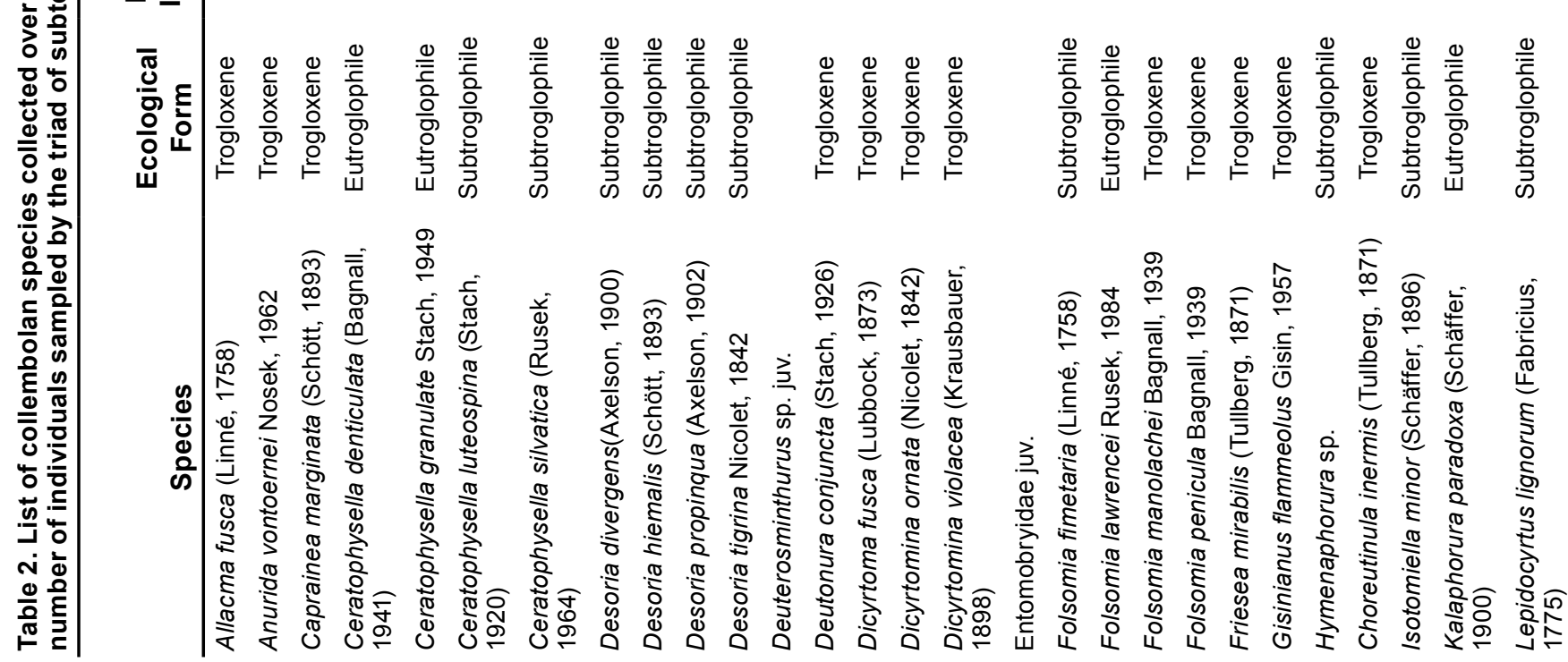




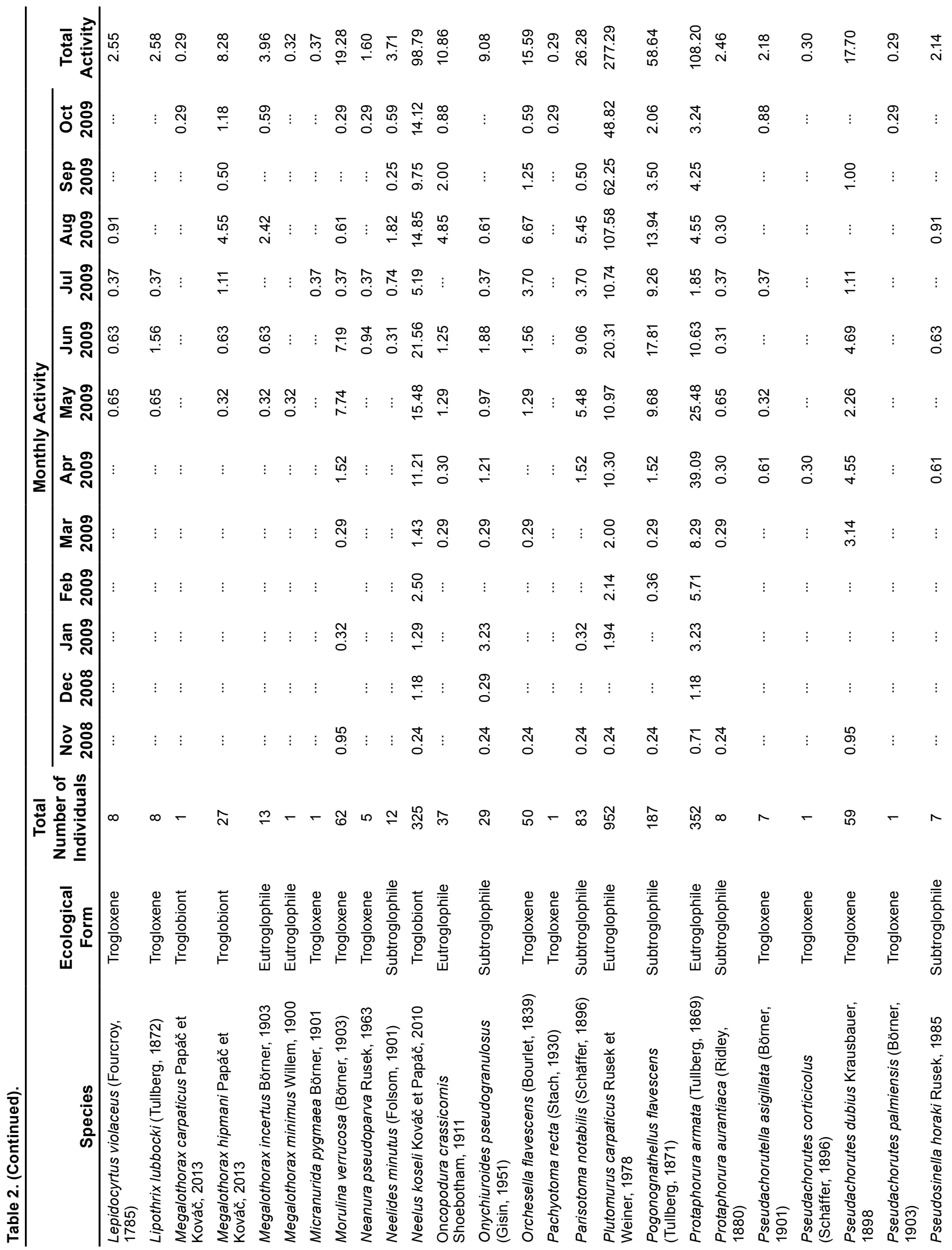




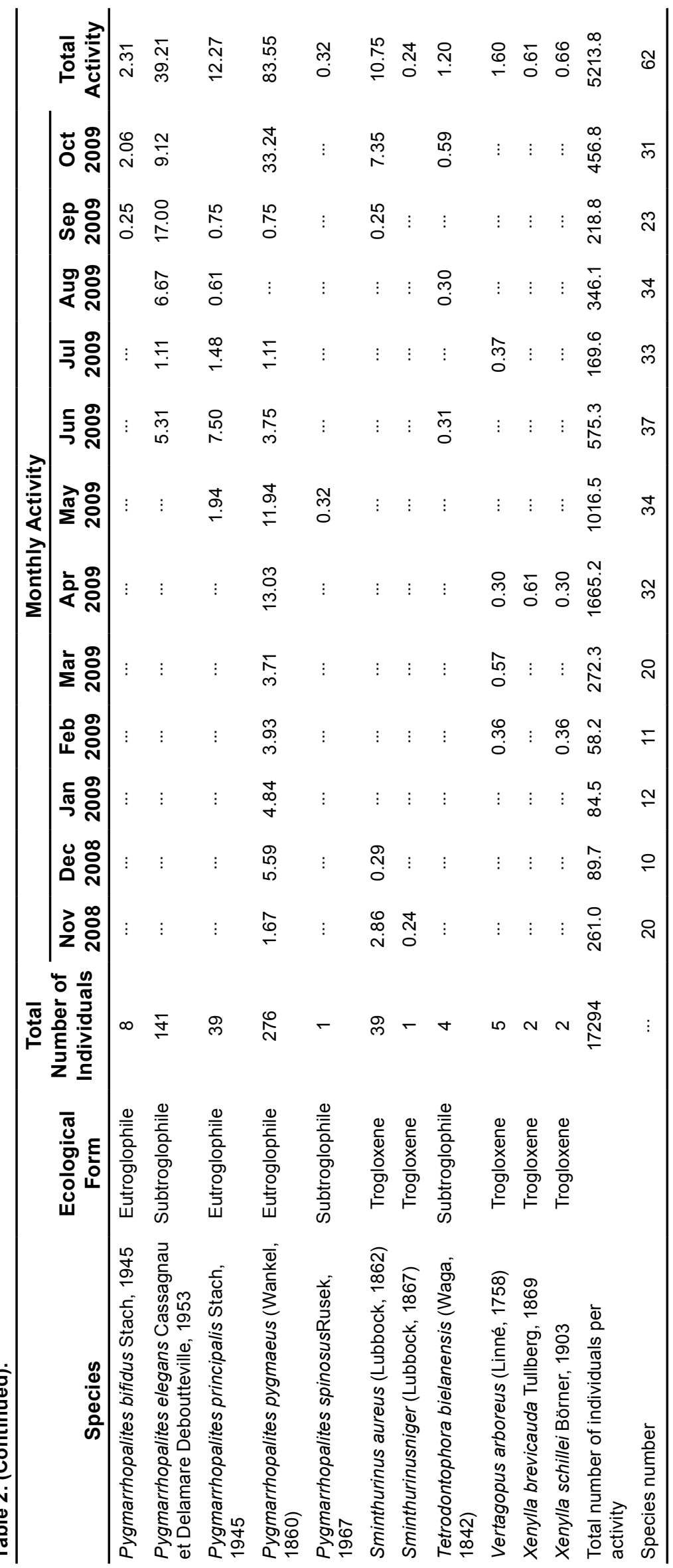

summer (May, June) and the second, after a short-term decline, in August. An exception was at the depth of $95 \mathrm{~cm}$, where only one noticeable activity peak (September) was found during the year.

\section{Collembolan Activity-Environmental Char- acteristics Relationship}

The redundancy analysis (RDA) revealed activity of particular collembolan species to be affected by thermal conditions fluctuating over the year. The eigenvalues of RDA ordination axes 1 and 2 were 0.337 and 0.153 , respectively, and they accounted for $61 \%$ of total variation. The species-environment correlations were 0.883 in axis 1 and 0.949 in axis 2 . The permutation test on all axes confirmed their statistical significance $(F=4.7, p=0.002)$. The resulting RDA biplot diagram (Fig. 3 ) illustrates that the spring months (April-May) were characterized by higher temperature ranges, and the species Ceratophysella silvatica, Desoria tigrina, Dicyrtomina ornata, Parisotoma notabilis, Pogonognathellus flavescens, and Pygmarrhopalites principalis were specific to these months. In contrast, Megalothorax hipmani, Neelus koseli, Oncopodura crassicornis, Protaphorura armata, Pygmarrhopalites elegans, P. pygmaeus, Plutomurus carpaticus and Pygmarrhopalites bifidus, associated with deeper layers of the scree slope profile, preferred rather lower temperature ranges and were typical for the autumn months (September-October). Dicyrtoma fusca and Lepidocyrtus lignorum, the species inhabiting the upper layers of the scree slope profile, were characteristic for mid-summer (July). Folsomia fimetaria and $F$. lawrencei were grouped with a higher temperature means during the summer months, while the occurrence of Desoria propinqua was associated with lower temperatures in late autumn (November) and early spring (March).

\section{Discussion}

Our earlier investigation (Rendoš et al., 2012) stressed the impact of seasonal temperature changes on the activity dynamics of higher invertebrate taxa inhabiting a limestone scree slope identical with the present study. Subsequent identification of the sampled invertebrates at the species level revealed Collembola to be the only taxon among the others that includes species representing all four ecological forms differing in degree of affinity to subterranean environment. We used these Collembola as a suitable model group for the first thorough study on activity dynamics of species communities in the shallow subterranean habitat with differences in 

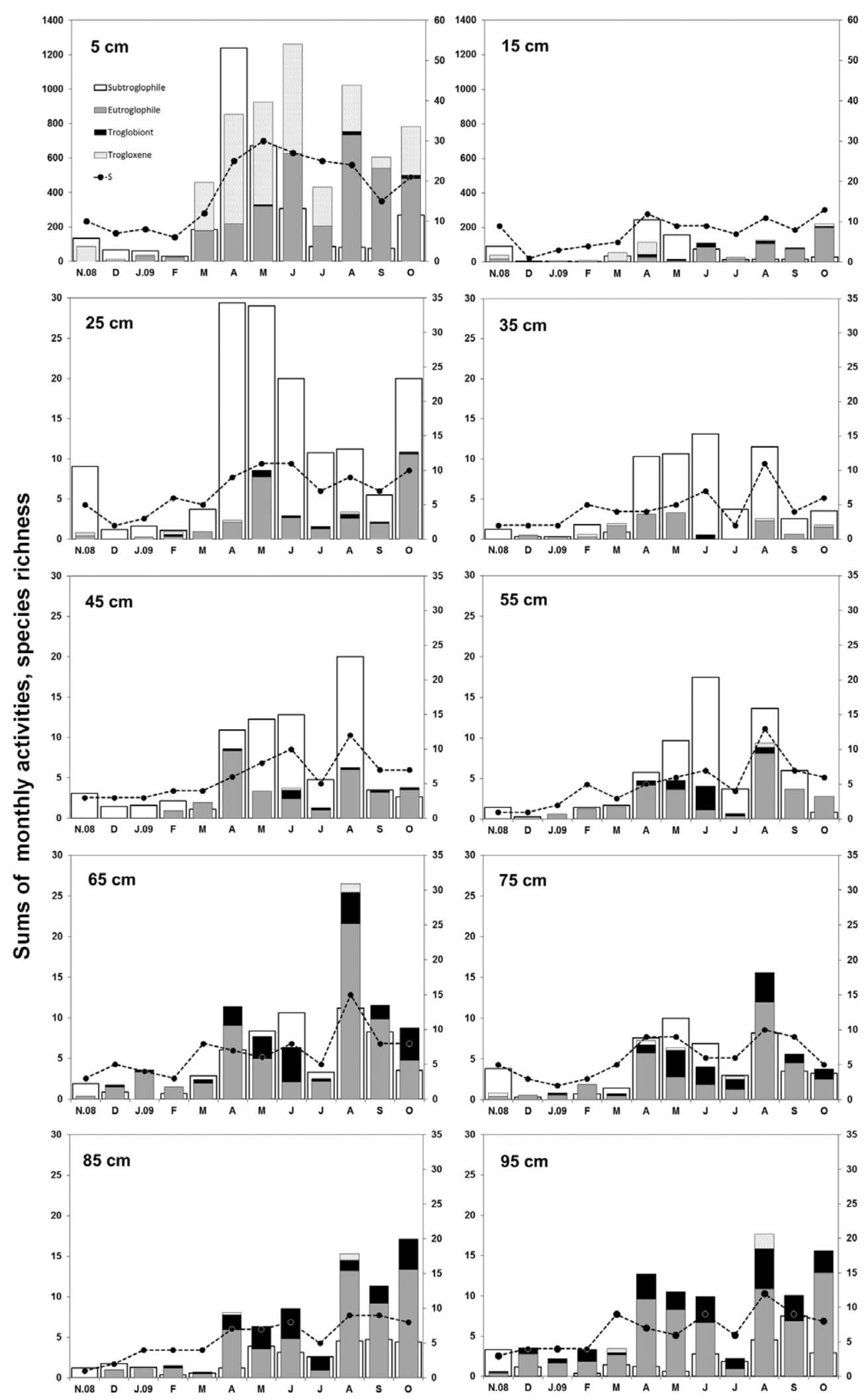

\section{Month}

Figure 2. Activity dynamics of four collembolan ecological forms during the study period (Nov. 2008Oct. 2009) along the scree slope profile. The activity (numbers) of subtroglophiles is depicted on the left $y$-axis, while the activity of trogloxenes, eutroglophiles, troglobionts and the collembolan species number (s) is depicted on the right y-axis. The graphs depicting collembolan activity at the depths of 5 and $15 \mathrm{~cm}$ have different scaling due to the large number of individuals captured. temperature fluctuations between scree depth horizons.

It is important to point out that burying subterranean pitfall traps may disrupt the structure of the scree slope habitat by impermanent clogging of the air-filled voids (Mock et al., 2015; Růžička and Dolanský, 2016), which may subsequently result in the mixing of invertebrate communities occupying the scree interior and the absence of some sensitive subterranean species for a period of several months to even years. As already noted by Rendoš et al. (2016), the effect of disruption of the scree slope structure on collembolans appears to be negligible. The depth distribution of particular ecological forms as well as activities of subterranean collembolan species, including troglobionts, were not found to be noticeably altered a month after the traps had been buried in the scree slope. The individual and species number may vary within a single studied site, as found by Jiménez-Valverde et al. (2015), who buried several traps individually across a scree slope. Our study was primarily focused on activity dynamics of Collembola communities along a scree depth profile during the year. To obtain as many individuals as possible with all ecological collembolan forms represented, we preferred to bury a triplet of subterranean pitfall traps into a single pit, being aware of possible variations in community structure within the studied forested scree slope.

In temperate regions, spring and autumn activity peaks occur in collembolans inhabiting leaf litter and 


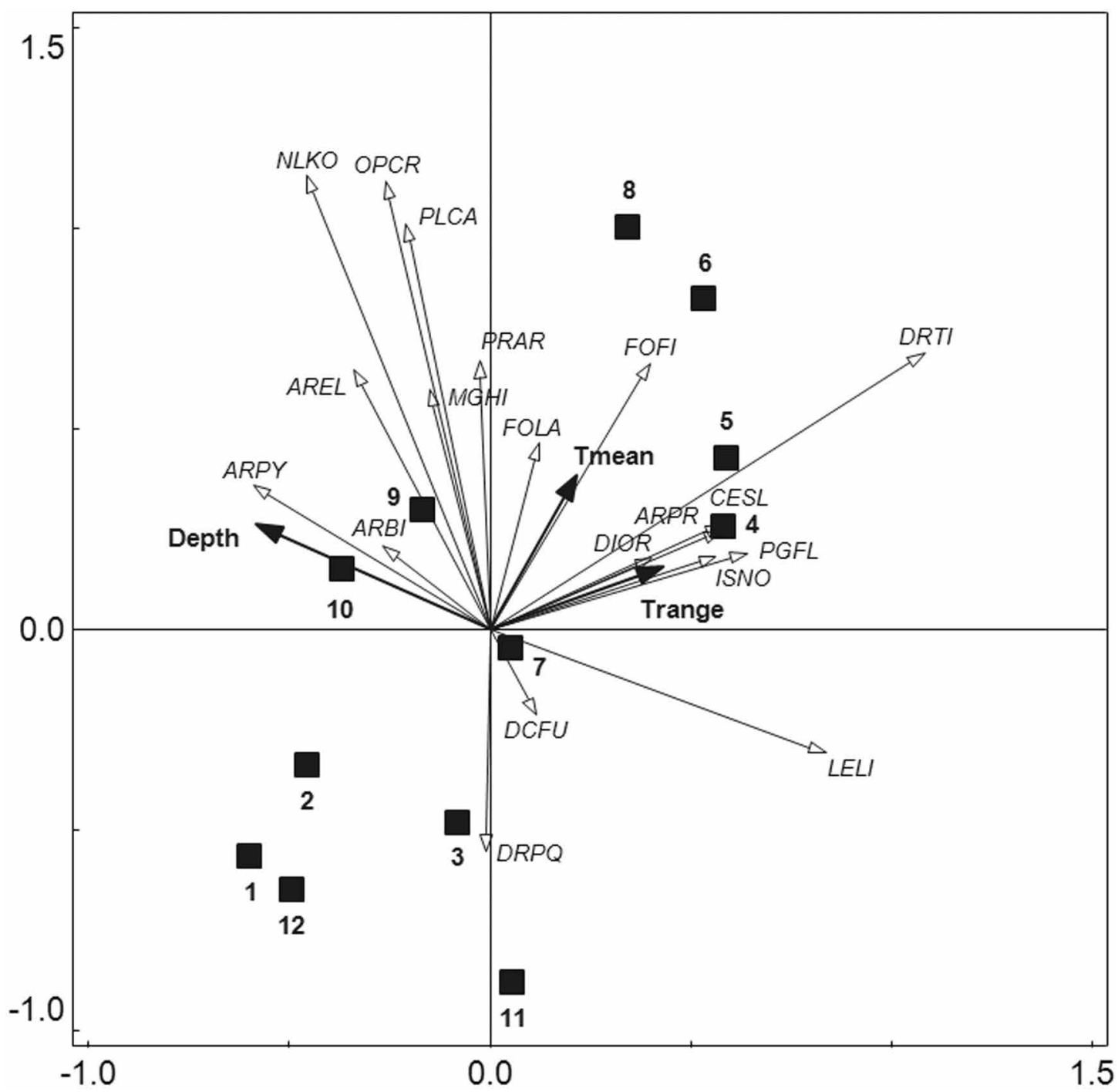

Figure 3. The RDA ordination biplot indicating associations of collembolan communities with months (black squares attended by Arabic numerals), depth, monthly temperature means (Tmean), and monthly temperature ranges (Trange). Collembolan species included in the analysis: Trogloxenes: DCFU - Dicyrtoma fusca, DIOR - D. ornata; Subtroglophiles: AREL - Pygmarrhopalites elegans, CESL - Ceratophysella silvatica, DRPQ

- Desoria propinqua DRTI - Desoria tigrina, FOFI - Folsomia fimetaria, ISNO - Parisotoma notabilis, LELI - Lepidocyrtus lignorum, PGFL - Pogonognathellus flavescens; Eutroglophiles: ARBI - Pygmarrhopalites bifidus, ARPR - Pygmarrhopalites principalis, ARPY - Pygmarrhopalites pygmaeus, FOLA - Folsomia lawrencei, OPCR - Oncopodura crassicornis, PLCA - Plutomurus carpaticus, PRAR - Protaphorura armata; Troglobionts: MGHI - Megalothorax hipmani, NLKO - Neelus koseli.

matic fluctuations during the year. The most prominent activity peak was observed in subtroglophiles occupying the uppermost levels of the depth profile in spring due to a mass occurrence of juvenile stages of some species (especially Desoria tigrina and Lepidocyrtus lignorum). Typically, the increase in collembolan activity, regardless of the ecological form, was rather moderate within the scree slope. In deeper layers, the activity peaks tended to be long-term, i.e. they lasted for several consecutive months, which was presumably associated with a reduction of daily temperature fluctuations resulting in prolongation of microclimate suitable for collembolan development.

Some studies consider deep layers of screes to represent a seasonal refuge for some invertebrates seeking temporary shelter during adverse environmental conditions. Nitzu et al. (2014), for instance, reported several Collembola and Coleoptera species inhabiting the surface of loose screes stabilized by a tiny amount of soil to migrate vertically into the scree interior during summer heat. Similarly, Polak (2012) observed subterranean coleopterans inhabiting an ice cave migrating into the adjacent MSS to avoid temperatures below the freezing point, which tend to occur in this cave during winter. In both cases, the authors found communities of subterranean and soil-dwelling species to overlap within the MSS. In our study, no species migration was recorded. Furthermore, our results suggest a strong spatial 
separation of troglobiont and trogloxene activity all year round. While troglobionts were active predominantly at lower and thermally more stable layers of the depth profile characterized by negligible fluctuations of daily temperatures, the second form was almost exclusively found in the uppermost layer possessing the most variable temperature parameters among all the investigated depths. Eutroglophiles as well as subtroglophiles were distributed along the entire depth profile throughout the year. This pattern of seasonal activity of Collembola ecological forms along the depth profile was presumably associated with the character of the scree slope site. In this study, we investigated a scree slope stabilized with a relatively thick layer of soil and overgrown with dense forest. On such types of scree slopes, the treetops greatly dampen high summer temperatures, thus protecting the soil surface from overheating and subsequent drying. In winter, the scree surface seems to be influenced by warmer air deposited in the scree voids, which is consequently reflected in attenuation of low temperatures. We recorded slight short-term frost on the scree slope surface in winter, although the air temperature above the scree dropped deep below the freezing point in the long term (continuously less than $-10^{\circ} \mathrm{C}$ ) in winter. Such thermal conditions seem to be favorable for all ecological forms of Collembola, and thus, none of them was forced to migrate into deeper layers of the scree slope profile.

The present study supported our hypotheses, and its results are consistent with observations from cave habitats that susceptibility to temperature fluctuations increases in proportion with degree of species affinity for subterranean environment (Tobin et al., 2013; Mammola et al., 2015; Raschmanová et al., 2018). Species limited to a subterranean environment are, in contrast to their soil-dwelling relatives, much more susceptible to desiccation due to the loss of most of the physiological mechanisms to control water balance. Since evaporation increases exponentially with rising temperature, subterranean species are considered to be capable of living exclusively within the areas with narrow temperature ranges (Peck, 1976; Howarth, 1980). The RDA analysis applied in this study revealed a general pattern of preferences of particular collembolan species to temperature parameters. Troglobionts and most eutroglophiles favored rather narrow temperature ranges deeper in the investigated scree slope profile in early autumn. On the contrary, trogloxenes and most subtroglophiles inclined to wider temperature ranges typical of upper parts of the scree profile during spring.

\section{Conclusions}

This study was focused on the activity dynamics of collembolan communities inhabiting the depth profile of a forested limestone scree slope - one of the most common types of terrestrial shallow subterranean habitats in temperate regions. During the year, fluctuations of activity dynamics were observed in all four ecological forms of Collembola and across the studied scree slope profile. Tolerance to temperature fluctuations decreases in proportion with the degree of affinity for subterranean environment. Subterranean species (troglobionts and eutroglophiles) tended to occupy deeper and thermally more stable parts of the depth profile, while soil-dwelling Collembola (trogloxenes and subtroglophiles) occurred mostly in the upper and thermally more variable parts of the depth profile. This study contributes to the general knowledge of invertebrate activity dynamics in forested scree slopes of the temperate zone.

\section{Acknowledgements}

This study was financially supported by grant 1/0346/18 from the Slovak Scientific Grant Agency Vega and by internal grant GaPU 21/2018 of the University of Prešov. We are very grateful to our colleagues and friends Michal Goga, Peter L'uptáčik, Edita Maxinová, and Andrea Parimuchová for their kind assistance during the fieldwork and laboratory work. We thank the Slovak Hydrometeorological Institute for providing us with meteorological data for the study site. Our thanks also go to D. McLean for linguistic correction of the manuscript and to the two anonymous reviewers who helped improve early version of the manuscript.

\section{References}

Bretfeld, G., 1999, Symphypleona, in Dunger, W., ed., Synopses on Palaearctic Collembola, Part 2: Görlitz, Germany, Abhandlungen und Berichte des Naturkundemuseums, v. 71, p. 1-318.

Christiansen, K.A., 1964, Bionomics of Collembola: Annual Review of Entomology, v. 9, p. 147-178. https://doi.org/10.1146/annurev. en.09.010164.001051

Coleman, D., Callaham, M., and Crossley,D., 2017, Fundamentals of Soil Ecology: Cambridge, The United States of America, Academic Press, p. 376.

Crouau-Roy, B., Crouau, Y., and Ferre, C., 1992, Dynamic and temporal structure of the troglobitic beetle Speonomus hydrophilus (Coleoptera: Bathysciinae): Ecography, v. 15, p. 12-18. https://doi.org/10.1111/j.1600-0587.1992.tb00002.x

Culver, D.C., and Pipan, T., 2008, Superficial subterranean habitats - gateway to the subterranean realm?: Cave and Karst Science, v. 35, p. $5-12$.

Culver, D.C., and Pipan, T., 2014, Shallow subterranean habitats: Ecology, Evolution and Conservation: Oxford, England, Oxford University Press, 304 p. https://doi.org/10.1093/acprof:oso/9780199646173.001.0001.

Deharveng, L, 2004, Insecta: Apterygota, in Gunn, J., ed., Encyclopedia of Caves and Karst Science: New York, The United States of America, Taylor and Francis, p. 962-964.

Giachino, P.M., and Vailati, D., 2010, The subterranean environment. Hypogean life, concepts and collecting techniques: Verona, Italy, World Biodiversity Association, WBA Handbooks, 132 p. 
Gilgado, J.D., Ledesma, E., Cuesta, E., Arrechea, E., de la Vega, J.L.Z., Sánchez-Ruiz, A., and Ortuño, V.M., 2014, Dima assoi Perez Arcas 1872 (Coleoptera: Elateridae): from montane to hypogean life. An example of exaptations to the subterranean environment?: Annales de la Societe Entomologique de France, v. 50, p. 264-271. https://doi.org/10.1080/00379271.2014.981421

Hochmuth, Z., 2008, Krasové územia a jaskyne Slovenska: Geographia Cassoviensis, v. 2, p. 1-210.

Hopkin, S.P., 1997, Biology of the Springtails: (Insecta: Collembola): Oxford, England, Oxford University Press, 340 p.

Howarth, F.G., 1980, The zoogeography of specialized cave animals: a bioclimatic model: Evolution, v. 34, p. 394-406. https://doi. org/10.1111/j.1558-5646.1980.tb04827.x

IUSS Working Group WRB, 2015, World Reference Base for Soil Resources 2014, update 2015. International soil classification system for naming soils and creating legends for soil maps: Rome, Italy, World Soil Resources Reports No. 106. FAO, p. 192.

Jiménez-Valverde, A., Gilgado, J.D., Sendra, A., Pérez-Suaréz, G., Herrero-Borgoñón, J.J., and Ortuño, V.M., 2015, Exceptional invertebrate diversity in a scree slope in Eastern Spain: Journal oflnsect Conservation, v. 19, p. 713-728. https://doi: 10.1007/s10841-015-9794-1

Juberthie, C., 1983, Le milieu souterrain: Étendue et Composition: Mémoires de Biospéologie, v. 10, p.17-65.

Juberthie, C., 2000, The diversity of the karstic and pseudokarstic hypogean habitats in the world, in Wilkens, H., Culver, D.C., and Humphreys, W.F., eds., Subterranean Ecosystems, Ecosystems of the World 30: Amsterdam, The Netherlands, Elsevier, p. 17-39.

Juberthie, C., and Decu, V., 2004, Interstitial habitats (terrestrial), in Gunn, J., ed., Encyclopedia of Caves and Karst Science: New York, The United States of America, Taylor and Francis, p. 984-986.

Juberthie, C., Delay, B., and Bouillon, M., 1980, Extension du milieu souterrain en zone non calcaire:description d'un nouveau milieu et de son peuplement par les Coléoptéres troglobies: Mémoires de Biospéologie, v. 7, p. 19-52.

Juberthie, C., Delay, B., and Bouillon, M., 1981, Extension du milieu souterrain superficiel en zone calcaire: Mémoires de Biospéologie, v. 8, p. 77-93.

Kováč, L'., 2000, A review of the distribution of cave Collembola (Hexapoda) in the Western Carpathians: Mémoires de Biospéologie, v. 27, p. 71-76.

Kováč, L'., and Papáč, V., 2010, Revision of the genus Neelus Folsom, 1896 (Collembola, Neelida) with the description of two new troglobiotic species from Europe: Zootaxa, v. 2663, p. 36-52. http://dx.doi.org/10.11646/zootaxa.2663.1.2

Kováč, L'., Parimuchová, A., and Miklisová, D., 2016, Distributional patterns of cave Collembola (Hexapoda) in association with habitat conditions, geography and subterranean refugia in the Western Carpathians: Biological Journal of the Linnean Society, v. 119, p. 571-592. https:// doi.org/10.1111/bij.12555

Laška, V., Kopecký, O., Růžička, V., Mikula, J., Véle, A., Šarapatka, B., and Tuf, I. H., 2011, Vertical distribution of spiders in soil: The Journal of Arachnology, v. 39, p. 393-398. https://doi.org/10.1636/P09-75.1

Mammola, S., Giachino, P.M., Piano, E., Jones, A., Barberis, M., Badino, G., and Isaia, M., 2016, Ecology and sampling techniques of an understudied subterranean habitat: the Milieu Souterrain Superficiel (MSS): The Science of Nature, v. 103, p. 88. https://doi.org/10.1007/s00114016-1413-9

Mammola, S., Piano, E., Giachino, P.M., and Isaia, M., 2015, Seasonal dynamics and micro-climatic preference of two Alpine endemic hypogean beetles: International Journal of Speleology, v. 44, p. 239-249. http://dx.doi.org/10.5038/1827-806X.44.3.3

Mammola, S., Piano, E., Giachino, P.M., and Isaia, M., 2017, An ecological survey of the invertebrate community at the epigean/hypogean interface: Subterranean Biology, v. 24, p. 27-52. https://doi.org/10.3897/subtbiol.24.21585

Mock, A., and Tajovský, K., 2008, Mecogonopodium carpathicum n. sp. (Diplopoda: Chordeumatida: Attemsiidae), a new troglophilic millipede from Slovakia: Zootaxa, v. 1778, p. 26-36. https://doi: 10.5281/zenodo.182245

Mock, A., Šašková, T., Raschmanová, N., Jászay, T., L'uptáčik, P., Rendoš, M., Tajovský, K., and Jászayová, A., 2015, An introductory study of subterranean communities of invertebrates in forested talus habitats in southern Slovakia: Acta Societatis Zoologicae Bohemicae, v. 79, p. 243-256.

Nitzu, E., Nae, A., Băncilă, R., Popa, I., Giurginca, A., and Plăiaşu, R., 2014, Scree habitats: ecological function, species conservation and vertical-temporal variation in the arthropod community: Systematics and Biodiversity, v. 12, p. 65-75. https://doi.org/10.1080/14772000.2013. 878766

Nitzu, E., Nae, A., and Popa, I., 2006-2007, Eco-faunistic study on the invertebrate fauna (Araneae, Collembola and Coleoptera) from the Vârghiş Gorge Natural Reserve (Eastern Carpathians, Romania), with special note on the micro-refugial role of the subterranean habitats: Travaux du Muséum National d'Histoire Naturelle “Grigore Antipa”, v. 45-46, p. 31-50.

Peck, S.B., 1976, The effect of cave entrances on the distribution of cave-inhabiting terrestrial arthropods: International Journal of Speleology, v. 8, p. 209-321. http://dx.doi.org/10.5038/1827-806X.8.4.1

Pipan, T., López, H., Oromí, P., Polak, S., and Culver, D.C., 2010, Temperature variation and the presence of troglobionts in terrestrial shallow subterranean habitats: Journal of Natural History, v. 45, p. 253-273. https://doi.org/10.1080/00222933.2010.523797

Polak, S., 2012, Vertical migration of the subterranean beetles as a respond to annual temperature fluctuations: 21th International Conference on Subterranean Biology, 2-7 September 2012, Košice, Slovakia, Pavol Jozef Šafárik University in Košice, p. 92

Pomorski, R.J., 1998, Onychiurinae of Poland (Collembola: Onychiuridae): Wrocław, Poland, Polish Taxonomical Society, 201 p.

Potapov, M.B., 2001, Isotomidae: in Dunger, W., ed., Synopses on Palaearctic Collembola, Part. 3: Görlitz, Germany, Abhandlungen und Berichte des Naturkundemuseums, v. 73, p. 1-603.

Racovitza, G., and Şerban, M., 1982, Recherches sur la dynamique de la faune du milieu souterrain superficiel: Travaux du Museum d'Histoire Naturelle "Grigore Antipa", v. 24, p. 33-42.

Raschmanová, N., Šustr, V., Kováč, L'., Parimuchová, A., and Devetter, M., 2018, Testing the climatic variability hypothesis in edaphic and subterranean Collembola (Hexapoda): Journal of Thermal Biology, v. 78, p. 391-400. https://doi.org/10.1016/j.jtherbio.2018.11.004

Rendoš, M., Mock, A., and Jászay, T., 2012, Spatial and temporal dynamics of invertebrates dwelling karstic mesovoid shallow substratum of NNR Sivec (Slovakia), with emphasis on Coleoptera: Biologi,: v. 67, p. 1143-1151. https://doi.org/10.2478/s11756-012-0113-y

Rendoš, M., Raschmanová, N., Kováč, L', Miklisová, D., Mock, A., and L'uptáčik, P., 2016, Organic carbon content and temperature as substantial factors affecting diversity and vertical distribution of Collembola on forested scree slopes: European Journal of Soil Biology, v. 75, p. $180-187$. https://doi.org/10.1016/j.ejsobi.2016.06.001

Rusek, J., 1975, Eine Präparationstechnik für Sprungschwänze und ähnliche Gliederfüsser: Mikrokosmos, v.12, p. 376-381.

Růžička, V., and Dolanský, J., 2016, Catching of spiders in shallow subterranean habitats in the Czech Republic: Arachnologische Mitteilungen, v. 51, p. 43-48. https://doi:10.5431/aramit5106

Růžička, V., and Kimeš, L., 2005, Spiders (Araneae) communities of scree slopes in the Czech Republic: The Journal of Arachnology, v. 33, p. 280-289. https://doi.org/10.1636/04-44.1 
Schlick-Steiner, B.C., and Steiner, F.M., 2000, Eine neue Subterranfalle and Fänge aus Kärnten: Carinthia II, v. 190 , p. $475-482$.

Sket, B., 2008, Can we agree on an ecological classification of subterranean animals?: Journal of Natural History, v. 42, p. 1549-1563. https:// doi.org/10.1080/00222930801995762

Ter Braak, C.J.F., and Šmilauer, S., 2012, Canoco reference manual and user's guide: software for ordination, version 5.0: Ithaca, U.S.A., Microcomputer Power, $496 \mathrm{p}$.

Thibaud, J.M., Schulz, H.J., and Gama, M.M., 2004, Hypogastruridae, in Dunger, W., ed., Synopses on Palaearctic Collembola, Part 4: Görlitz, Germany, Abhandlungen und Berichte des Naturkundemuseums, v. 75: p. 1-287.

Tobin, B.W., Hutchins, B.T., and Schwartz, B.F., 2013, Spatial and temporal changes in invertebrate assemblages structure from the entrance to deep-cave zone of a temperate marble cave: International Journal of Speleology, v. 42, p. 203-214. http://dx.doi.org/10.5038/1827806X.42.3.4

Zacharda, M., Gunde, M., and Růžička, V., 2007, Thermal regime of three low elevation scree slopes in Central Europe: Permafrost and Periglacial Processes, v. 18, p. 301-308. https://doi.org/10.1002/ppp.598. 
Appendix 1. Values of monthly minimum (Min) and maximum (Max) collembolan activities (calculated per 30 days) and species numbers recorded during the year in individual subterranean pitfal traps.

\begin{tabular}{|c|c|c|c|c|c|c|c|c|c|c|c|c|}
\hline \multirow{3}{*}{ Depth, cm } & \multicolumn{6}{|c|}{ Activity } & \multicolumn{6}{|c|}{ Species Number } \\
\hline & \multicolumn{2}{|c|}{ Trap 1} & \multicolumn{2}{|c|}{ Trap 2} & \multicolumn{2}{|c|}{ Trap 3} & \multicolumn{2}{|c|}{ Trap 1} & \multicolumn{2}{|c|}{ Trap 2} & \multicolumn{2}{|c|}{ Trap 3} \\
\hline & Min & $\operatorname{Max}$ & Min & Max & Min & Max & Min & $\operatorname{Max}$ & Min & $\operatorname{Max}$ & Min & Max \\
\hline 5 & 3.2 & 657.1 & 33.9 & 1234.5 & 21.4 & 2376.4 & 2 & 22 & 2 & 20 & 4 & 21 \\
\hline 15 & 2.1 & 107.3 & 1.0 & 256.4 & 9.6 & 384.5 & 1 & 8 & 1 & 7 & 1 & 8 \\
\hline 25 & 1.1 & 30.0 & 1.7 & 35.8 & 1.0 & 61.0 & 1 & 6 & 1 & 10 & 1 & 7 \\
\hline 35 & 1.0 & 18.4 & 1.1 & 18.2 & 0.9 & 16.5 & 1 & 5 & 1 & 6 & 1 & 5 \\
\hline 45 & 0.9 & 29.1 & 0.9 & 43.6 & 1.0 & 26.3 & 1 & 8 & 1 & 8 & 1 & 6 \\
\hline 55 & 1.7 & 30.9 & 0.9 & 38.4 & 0.7 & 26.1 & 1 & 6 & 1 & 8 & 1 & 5 \\
\hline 65 & 1.1 & 62.7 & 1.1 & 52.7 & 1.4 & 20.9 & 1 & 9 & 1 & 11 & 2 & 6 \\
\hline 75 & 1.0 & 35.5 & 0.9 & 40.0 & 1.1 & 24.5 & 1 & 7 & 1 & 10 & 1 & 6 \\
\hline 85 & 0.7 & 26.4 & 1.1 & 16.4 & 1.7 & 59.1 & 1 & 6 & 1 & 7 & 1 & 7 \\
\hline 95 & 1.0 & 20.9 & 0.9 & 18.2 & 2.9 & 59.1 & 1 & 8 & 1 & 9 & 2 & 8 \\
\hline
\end{tabular}

